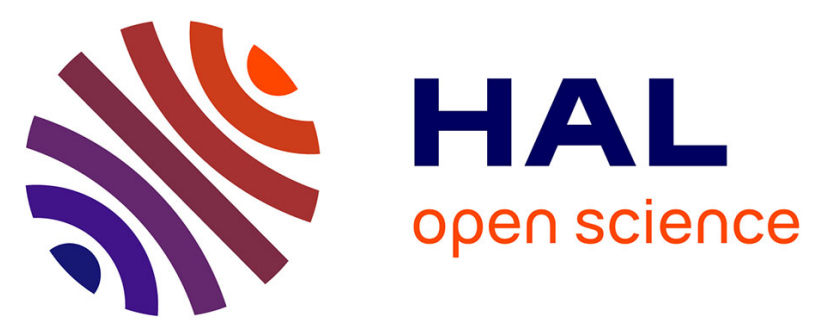

\title{
Discovering the African Freshwater "Torpedo": Legendary Ethiopia, Religious Controversies, and a Catfish Capable of Reanimating Dead Fish
}

\author{
Marco Piccolino, Stanley Finger, Jean-Gaël Barbara
}

\section{- To cite this version:}

Marco Piccolino, Stanley Finger, Jean-Gaël Barbara. Discovering the African Freshwater "Torpedo": Legendary Ethiopia, Religious Controversies, and a Catfish Capable of Reanimating Dead Fish. Journal of the History of the Neurosciences, 2011. halshs-03090662

\section{HAL Id: halshs-03090662 \\ https://shs.hal.science/halshs-03090662}

Submitted on 11 Jan 2021

HAL is a multi-disciplinary open access archive for the deposit and dissemination of scientific research documents, whether they are published or not. The documents may come from teaching and research institutions in France or abroad, or from public or private research centers.
L'archive ouverte pluridisciplinaire HAL, est destinée au dépôt et à la diffusion de documents scientifiques de niveau recherche, publiés ou non, émanant des établissements d'enseignement et de recherche français ou étrangers, des laboratoires publics ou privés. 


\title{
Discovering the African Freshwater "Torpedo": Legendary Ethiopia, Religious Controversies, and a Catfish Capable of Reanimating Dead Fishes
}

\author{
Marco Piccolino, Stanley Finger, and Jean-Gaël Barbara
}

Dr. Marco Piccolino

Dipartimento di Biologia ed Evoluzione and Center of Neurosciences

Università di Ferrara

Via Borsari 46,

44100, Ferrara

Italy

E-mail: pic@dns.unife.it

Dr. Stanley Finger

Department of Psychology

Washington University

St Louis, MO, 63130 USA

Tel. 3149356513 Fax 3149357588

E-mail: sfinger@wustl.edu

Dr. Jean-Gaël Barbara

Laboratoire de Neurobiologie des Processus Adaptatifs

Université Pierre et Marie Curie, Case 14,

7 quai Saint Bernard,

75005, Paris

jean-gael.barbara@snv.jussieu.fr

Running Title: Electric Catfish and Ethiopia. 


\begin{abstract}
The electric catfishes of African rivers and lakes, once depicted on Egyptian tomb art, have been largely overlooked in histories and reviews of electric fish biology and animal electricity. This article examines how Westerners, especially Dominican and Jesuit missionaries, discovered them in Ethiopia and other parts of Africa at the beginning of the seventeenth century. What transpired took place against the backdrop of tales involving the Bible, Prester John's mythical empire, and imaginary animals with fabulous powers. In effect, how they were found is related attempts to convert Ethiopian Christians to true Catholicism, hopes of discovering great riches, and opportunities to trade, and not with the efforts of skilled natural philosophers to document and conduct experiments on the wildlife of this continent. Nevertheless, the early descriptions by Europeans circulated, and during the next century these catfishes began to be used in experiments that helped to make animal electricity a reality.
\end{abstract}

Keywords: electric catfish, Malapterurus electricus, electric fish, torpedo, animal electricity, Ethiopia, Prester John, religion, Jesuits, seventeenth century, Portuguese, Urreta, Paez, Telles, Fernandes,

Godinho, Jobson,

Purchas. 
One cannot overstate the important role played by electric fish in the emergence of the physiological notion of animal electricity, especially with regard to nerve conduction and muscle excitability, two basic concepts of modern electrophysiology (Piccolino and Bresadola, 2003; Finger and Piccolino, 2011). This new way of thinking about physiology also played a transformational role in medicine, and in the transformation of physics with Alessandro Volta's invention of the electric battery (Volta, 1800; Pancaldi, 1990; Piccolino 2000). It materialized during the second half of the eighteenth century, beginning with three types of unusual fishes known to have benumbing or "torporific" powers that could even be felt by people through certain intermediaries --- actions that prior to this time seemed almost inexplicable and resulted in much speculation.

The best known of these fishes were the flat torpedo rays, of which there are many varieties. Long known to the ancients (e.g., Hippocrates, Plato, Aristotle), these saltwater fishes are ubiquitous, but are especially common in the warm Mediterranean Sea. The most common European varieties are small and deliver shocks that typically will numb no more than a hand up to the wrist or maybe the elbow.

The second of these fishes, one often called an "electric eel," is actually a single species of knifefish and not an eel. It is found in sluggish South American rivers and can generate shocks that could topple even a strong man. It is this feature that drew eighteenth-century natural philosophers to it, especially the Dutch, who had settlements in the Guianas and saw similarities between the shocks of these fish and the release of electricity from a charged Leyden jar (Ingram, 1750; Allamand, 1754; Van der Lott, 1762; for reviews, see Koehler, Finger and Piccolino, 2009; Finger and Piccolino, 2011).

The last of these fishes, the electric catfish (today categorized as Malapterurus electricus) was once thought to be a single species but is now considered a family of fishes (see Norris, 2002; Nelson, 2006) (Fig. 1). They typically deliver shocks that are considerably more powerful than those of small European torpedoes $(50-75 \mathrm{~V})$, although they only have about half the voltage of the eel (700 V) (Moller, 1995). Found in tepid African rivers and lakes, they remained less well known to Europeans than the other two types of fishes, even though Westerners first encountered them and the eel at about the same time, this being when they began to sail to and explore Africa and South America.

Nevertheless, prior the period 1772-1776, when Englishman John Walsh succeeded in demonstrating the electrical nature of the torpedo's and the eel's shocks (Walsh, 1773; Piccolino and Bresadola, 2002; Piccolino 2003; Finger and Piccolino, 2011), the electric catfishes had already helped to shape what would transpire in this exciting branch of natural philosophy. That is, what had been learned about them literally helped to charge the atmosphere and open minds to the possibility that at least some of God's creatures might be electrical.

The overlooked early history of the electric catfishes is fascinating, particularly the events underlying how Westerners discovered and described them at the beginning of the seventeenth century, and how they were repeatedly confused with the other species of electric fishes. It involves Portuguese missionaries in Ethiopia, fables and myths about this part of Africa, and influential writers with competing religious agendas. Yet without some knowledge of the historical context in which the electric catfishes were discovered, it is impossible to understand why and how the new information on its existence rapidly reached the literati of the age. 
In this historical review, we shall attempt to show how all of these things came together, as we examine documents not written by skilled natural philosophers who ventured to Africa to study living nature, but rather by men of the cloth, traders, and others with entirely different motives. Since only one type of torporific catfish was recognized during this period, we shall refer to "the catfish" in the singular in this history. (For Ancient Egyptian descriptions, Middle Eastern treatises from the start of the second millennium AD, and additional information on how the catfish's shocks were viewed over the ages, see Finger and Piccolino, 2011.)

\section{Ethiopia and Early Relations with Europe}

As intimated above, it is important to begin with some words about the early history of Ethiopia, since it is central to understanding the Western discovery of the electric catfish (for more on early Ethiopian history, see Castanhoso, 1564; Whiteway, 1902; Conti Rossini, 1894, 1928, 1940a, 1941; Wallis Budge, 1928; Cerulli, 1943-47, 1968; Caraman, 1985; Pennec, 2003; Alfonso Mola and Martinez Shaw, 2004; Alonso Romo, 2006). Although largely unknown to the West until the 1500s, Ethiopia had long had important religious and cultural links with Middle Eastern civilizations. Following the establishment of Christian sovereignties in the Middle East and the influx of Europeans during the Crusades (10951291), increased information about this part of Africa began to flow into Europe. Nevertheless, real facts were intermingled with myths that exaggerated the richness of the land, its history, and the powers of its leaders. This was especially true with regard to the legend of Prester John and his mythical empire.

The story of Prester John had been one of the most popular myths of the Middle Ages, rivaling those about Parsifal, the Knights of Round Table, and the adventures of Roland (Zarncke, 1879-83; Hofmeister, 1912; Doresse, 1957; Slessarev, 1959; Zaganelli, 1992; Wagner, 2000). As with other popular medieval legends, it developed over time and was linked to other fabulous narrations (Fig. 2).

The term "Presbiter Iohannes" seemingly first appeared in a chronicle written by Otto von Freising, a German bishop and historian, who recorded a narration he had heard in 1145 from Hugh, a bishop in the French-Syrian town of Jabala (Hofmeister, 1912). Hugh related that Prester John was the religious and political chief of a group of Nestorian Christians living beyond Persia and Armenia. After defeating the Persians and Medians in what is now Iran, he had set forth for Jerusalem to serve the Church, but failing to get there, returned back to his own country. Hugh added some colorful notations to this narration, among them that Prester John was descended from the three King Magi and possessed riches that could only be imagined.

As the news of Hugh's narration spread, it generated images of a powerful and rich lord in a far off empire, a leader who could save Christianity from the hostile Muslims. Not surprisingly, more soon began to be heard from the Holy Land about Prester John, making him seem even more real. Around 1177, Philip, a Papal physician, reported a conversation he had about him in the Holy Land with dignitaries of a Christian kingdom in "India." He was told that Prester John wished to install a church near Saint Sepulcher and desired to be instructed in Catholic faith. The kingdom alluded to in these discourses was likely Ethiopia, one of the three Indias at the time.

Vague allusions to this mysterious king took on greater meaning near the end of the century, when letters (of which scholars reference more than 100) supposedly signed by a 
"Prester John of the Indias" were sent to the Pope and various European Christian sovereigns. Written in Latin and Greek, Prester John presented himself as a pious and humble priest, yet also as the lord of the largest empire in the world, one extending over the three Indias, with 72 kings paying tribute to him. His empire was said to contain palaces made of gold and precious stones, manna and a water source that could keep one young and healthy for 500 years, strange but obedient beings (e.g., the Gog and Magog, Amazons), and exotic plants and animals with remarkable powers. People lived peacefully in this land of milk and honey, without envy or hate, safely protected by their beneficent leader.

An important feature of this legend, and one that would certainly have appealed to people during the Middle Ages, was Prester John's declared intention to "visit the Holy Sepulchre with a very great army, as it fits to [his] Majesty to humiliate and defeat the enemies of the Cross of Christ and to exalt his blessed name" (Wagner, 2000, p. 357). The power of this massive army would have been comforting to the Christians, given the disappointments of the Crusades and the dangers now threatening Europe, including those from Genghis Khan's powerful Mongol hordes.

As can easily be envisioned, the search for Prester John's Empire began in earnest soon after the arrival of these letters. Signs of his presence were initially sought in the reports from the first European voyagers to the Orient, including those of Marco Polo and William of Rubruck. Over time, however, the likely location shifted from the East to the African "India," and particularly to Ethiopia. This new location was enhanced by reports from Westerners traveling to the Holy Land, where some met with Ethiopian clergymen, by what European traders were gleaning from conversations with sub-Saharan Africans, and by an Ethiopian delegation that had been sent from Jerusalem to the Ecumenical Council of Florence (in 1439). But despite attempts by popes and kings to establish diplomatic and political contacts with the Ethiopians, stable relationships were not still established in the fifteenth century, when Europeans began to sail down the coast of Africa looking for trade routes to the East.

In 1487, King João II of Portugal decided to send a diplomatic delegation to Ethiopia, in order to bring the two countries closer together. Shortly after this, in 1494, Pope Alexander VI assigned the eastern regions of the rapidly expanding world to Portugal and the western ones to Spain. With this edict, more Portuguese began to head for Ethiopia, circumventing the land routes with their natural and even more daunting human perils. When the Ethiopians requested a military alliance against the Muslims, diplomatic missions from Portugal to the new Abyssinian ruler, Lebna Dengel, followed.

Francisco Alvares (or Alvarez), a Franciscan Father who served the Portuguese King Manuel I, was a member of the delegation that eventually established good ties between the two countries, and he was the first person to provide a first-hand account of the country (Alvares, 1540: Fig. 3). Being a priest he focused on the local religion, which mixed Christianity with Jewish and Islamic practices. But although his book was intended to be a "true history," he also wrote about abundant sources of gold, precious stones, and other coveted natural resources, and this had a strong impact on his many readers, reigniting beliefs about the location of Prester John's wondrous empire.

During Alvares' last years in Ethiopia, Ahmad ibn Ibrahim al-Ghazi (Gragn, "The Left Handed") started his military conquest of Ethiopia, killing many people, pillaging villages, and burning churches. Facing the collapse of his Christian country, Lebna Dengel requested European help, and the King of Portugal responded by dispatching soldiers with firearms to help repel the Muslim invaders. The initial encounter took place in 1542, and it resulted in a 
Portuguese victory. Although others followed, when the Portuguese faced the main body of Ahmad's army, reinforced by a large Turkish force, they were routed and their leader, Cristóvão da Gama (a son of the legendary navigator), was captured and killed. The Portuguese survivors later regrouped and the final battle took place near Lake Tana in 1543, where Ahmad was killed with a single shot to the breast (whether by a Portuguese or an Ethiopian soldier is debated) and his soldiers sent fleeing (Castanhoso, 1564; Basset, 1882).

Following the success of Portuguese military expedition, the Ethiopian emperor was open to accepting greater political and religious contacts with Europe. Now, however, the problem of Ethiopian orthodoxy came to the fore and the task of bringing the Ethiopian Christians into the Roman Church was entrusted to the recently founded Society of Jesus (the Jesuits, originating around 1550).

In 1554, the Pope Julius III appointed João Nuñes Barreto, a Portuguese Jesuit, as the first Catholic Patriarch of Ethiopia. He also designated two new bishops, Andrés Oviedo from Spain and Melchior Carneiro from Portugal, to go to Ethiopia. But before his bishops could be dispatched, a diplomatic mission was sent ahead to make arrangements with the new emperor, Gelawdewos or "Claudius," so as to assure the success of the mission. The subsequent engagement resulted in a treatise on Ethiopian religious errors that demanded immediate correction --- a dogmatic position with which the emperor strongly disagreed, stimulating him to write a famous document in 155, one known as the Confession of Gelawdewos (Ludolf and Wansleben, 1661; Conzelman, 1895).

Claudius understood that the Ethiopian Church was an important part of the national identity and that it promoted stability within his empire. After all, the Ethiopian kings traced their lineages back to King Menelik, the son of King Solomon and to Makeda, the Queen of Sheba. The linkage to the Old Testament accounted for why all the Ethiopian emperors had the generic name David and the title King of Zion. Faced with this reality, only Bishop Oviedo was sent to Ethiopia in 1557, hoping to achieve some reconciliation. He did not achieve everything he wanted, but Claudius did make some minor concessions.

The situation deteriorated in 1559, after Claudius died and his suspicious brother Minas became emperor. Fearing loss of control, Minas first imposed severe restrictions on the missionaries and then exiled them to a place they called Fremona, in memory of Saint Frumentius, the Syrian monk who had introduced the Christian religion to Ethiopia in the fourth century. Bishop Oviedo died there (probably in 1577), and within two decades there were no surviving members from the first Jesuit mission in Ethiopia.

The decision to try to promote Catholicism in Ethiopia yet again came directly from King Philip, who became sovereign of both Spain and Portugal, which were now united. Pedro Paez (Paéz, Pais), a cultured Spanish monk educated in Portugal, was entrusted with the new mission but was detained in what is now Yemen for 15 years and did not arrive in Fremona until 1603. João Gabriel, the captain of the Portuguese soldiers, whose mother was Ethiopian and father Italian, assisted him at the end of his trip, and as we shall see below, he would convey personal knowledge of the shocks of the African "torpedo" (Conti Rossini, 1941).

Paez then worked diligently and intelligently to promote Catholicism in Ethiopia, drawing on his exceptional linguistic abilities (he had learned Amharic and Geez) and understanding of the social characteristics and rich cultural history of Ethiopians. He served as one of Emperor Susenyos advisors and converted many influential Ethiopians to his 
religion prior to his death in 1622. Under his guidance, even King Susenyos began to embrace Catholicism.

\section{$\underline{\text { A Dominican's Books and Jesuit Agendas }}$}

The Jesuits were now also making major inroads in other parts of the world. Their missions in Persia, Ceylon, and Bengal were very successful, and they had realistic prospects for important conversions in other parts of the Far East, including China, Tibet, and Japan. It was against these Portuguese Jesuit successes that Luis (Luys) de Urreta, Spanish Dominican, wrote his polemics about Ethiopia, glorifying Dominican accomplishments while attempting to undermine Jesuit claims (Conti Rossini, 1940b).

Urreta was able to attract a vast audience to his two-volumes (published in 1610 and 1611 but often sold together; Fig. 4), by broadening its scope to include a general history of the African country, still largely unknown to Europeans. More at ease writing about religious legends than facts, with a great proclivity for verbosity, and with his Dominican agenda in the spirit of the Catholic Counterreformation, he transformed the real Ethiopia into a fictitious world to draw on his readers' emotions and rally their religious feelings. Indeed, Urreta's Ethiopia was a rich, splendid, and ideal country. It was a land of natural wonders, untold wealth, utopian social systems, and miracles. Urreta's Ethiopia was, in fact, very much the land of Prester John, the most Christian of Kings, whose legends, although somewhat dated, were now given new life.

Juan de Baltasar (Baltazar, Balthasar, or Baldassarre), an Ethiopian proclaiming himself a monk of aristocratic ascent (but likely a charlatan), who Urreta had met at his own convent in Valencia, served as a key source for his material (Lefevre, 1944-47). In the Prologo to the book from 1610, Urreta describes him as "Military Commander of the Order of Saint Antony Abbott, and member of the guard of the King of Ethiopia, called Prester John of the Indias" (italics ours), further pointing out that he was a nobleman whose ancestry could be traced back to the legendary Magi.

Urreta's books encompassed various aspects of Ethiopian geography, history, natural history, social customs, and religious organization, all of which contributed to its success. The wonders of Mount Amarà, the site of a library far greater than any other in the world (containing texts by Noah, Abraham, Solomon, and "writings of Enoch, the seventh descendent of Adam") where the heirs of the imperial family were educated, the splendid palaces, the spectacular gardens, and other magnificent manmade and natural treasures are presented in such fine detail that readers would not have guessed that this was a total fabrication.

This Ethiopia was not the Ethiopia encountered by the Jesuit missionaries actually living there, which they now were compelled to describe very realistically. But although this Jesuit drive to describe the true Ethiopia would result in some of the first realistic descriptions of the torporific river fish in print, it must be noted that another Dominican, who was actually serving as a missionary in Africa, had actually described what could only be this catfish a year before Urreta's first fanciful book had been printed, mobilizing the Jesuits.

\section{The First Western Text Describing the Torporific Catfish}

The first mention of the electric catfish by a European that allows for its unequivocal identification appeared in 1609 and was written by João dos Santos, a Portuguese Dominican monk. His Ethiopia oriental e varia historia de cousas notaveis do Oriente ("Oriental 
Ethiopia and Various History of Remarkable Things about the Orient"; Fig. 5) has a title that can be confusing. This is because he will provide a description of the nature, customs, and history of what is now mainly Mozambique. Hence, his narration only minimally concerns what we now think of as Ethiopia, a land-locked country he did not personally visit. Yet the somewhat generic word "Ethiopia" tended to include this part of Africa, where he did his missionary work, at this time.

Dos Santos' fish, found in Mozambique's Sofala River, is described in a passage that we translate from the Portuguese as follows:

A certain species of fish lives in the freshwater rivers of this region. It is called peixe tremedor by the Portuguese dwellers and Thinta by the Africans [Cafres], having the property that nobody can hold it in his hand when it is alive. If someone touches the fish, it causes him so much pain in his hand and entire arm and so disrupts the joints that he immediately lets the fish go free. When the fish dies, however, it is like any other fish, and it is very tasty and esteemed as food. The natives say that enchantments are made from the skin of this fish, and also that it is a strong medicine against the colic, when it is roasted and ground and taken in a glass of wine. The largest fish of this species has the dimension of a cubit. This fish has a skin like that of a smooth hound-fish [dogfish], almost black, and it is very rough and thick. (Dos Santos, 1609, p. 39)

Although Dos Santos' description would be quoted in some later books on Ethiopia (see below), his own book had a relatively small circulation. In contrast, some of the early-seventeenth-century Jesuit descriptions of the river fish had a considerably larger readership. But although they appeared in books that circulated more broadly, these books came from authors who never stepped foot in Ethiopia or even in other parts of Africa. Nicholao Godinho and Balthasar Telles stand forth in this regard, and they were motivated to refute what Urreta had written, and to provide accurate descriptions of what Ethiopia, its people, and its natural wonders were really like.

Godinho's Book and Fernandes' Letter

As stated, Urreta's $(1610,1611)$ texts about Ethiopia triggered strong and immediate responses from the Jesuits in Europe. One, written by Fernão Guerreiro in Lisbon, came forth in 1611, the year of Urreta's second book. Guerreiro challenged Juan de Baltasar as a credible source.

In 1615, a more complete and somewhat official refutation of what the Spanish Dominican had written was published. Nicholao Godinho's text was titled De Abassinorum rebus, déque Aethiopiae Patriarchis Ioanne Nonio Barreto \& Andrea Oviedo ("On Abyssinian Matters, and on the Ethiopian Patriarchs Joan Nuñez Barreto and Andrés Oviedo"). Although he wrote his book with the declared intention of refuting all of Urreta's fantastic assertions one-by-one, Godinho never mentioned the Dominican by name. Instead, he referred to him as the novus auctor ("new author") or with some related term.

Godinho lived most of his life in Rome, where he was nevertheless ideally positioned to publish extensive information about Ethiopia. This was because he held a position with the Society of Jesus as a reviser of works to be published in Portuguese. With this assignment, he had direct access to important documents from Africa. Additionally, Godinho had held the important position of "Praefectus Studiorum" ("Director of studies") at 
the most important Jesuit teaching institution, the Collegium Romanum, from 1608 to 1611. Further, he had already written a book about the Jesuit missionaries in Africa (Godinho, 1612).

The description of the Abyssinian "torpedo" appears in Chapter XVII of his book from 1615, and this is the second of the Portuguese descriptions of the electric catfish to appear in print (Fig. 6). This chapter deals with the soil, plants, and animals of Ethiopia, and it is based on a letter that Father Antonio Fernandes had written. Fernandes was very close to Father Paez, then head of the Jesuit mission. In 1613, he was entrusted with bringing some letters back to Europe, documents in which Emperor Susenyos would proclaim his intention of converting to Catholicism, while also asking for military support. Although unable to make the trip, Fernandes would remain in high standing and would lead the mission after Paez's death in 1622.

Fernandes' letter containing the description of the torporific river fish dates back to 1610, although the year is mistakenly given as 1620 in Godinho's book. After describing some real animals (e.g., crocodiles and hippopotamuses) in the region of Lake Tana, where the Blue Nile originates, we find what Godinho refers to as a faithful transcription of what Fernandes had written about the strange freshwater fish. The passage translates as follows:

The torpedo fish, well known for the strongly debated opinions and controversies of the philosophers, can also be found in these rivers and lakes. On the basis of the experiences of many people, it appears that this fish is endowed with such a contrivance that, if handled by somebody with his hand, it does not cause problems while it remains still. On the other hand, if the fish moves a little, it tortures the body of the person who holds him so much that the arteries, joints, nerves, connections of the body parts, in short all the components of his body, feel an intense affliction accompanied by stupor. As soon the fish is released from the hand, the pain and stupor fade away.

It continues with a myth:

Superstitious Ethiopians believe that this fish has the power of chasing demons from human bodies, as if these [evil] spirits were sensible to the same afflictions that torture corporeal bodies. People say (I had no direct experience of this) that, if a torpedo is placed among dead fish, and if it then moves, the fishes that have contact with it will be animated to a somewhat arcane motion, as if they were alive. Let those who investigate natural things try to ascertain the cause of this phenomenon, and to search for the force of the motion transmitted by the torpedo to the dead fish. These fish can be found in abundance in Nile River at the extreme limits of the Province of Goyam, where there is a bottomless pool with perennial and marvelous sources of churning waters. Here the Nile River begins. (Godinho, 1615, Book I, Chapter XVII, p. 18)

There is no physical description of the fish in this passage --- nothing, to suggest this is not just some sort of a torpedo. If anything, by tying this fish to what ancient philosophers had written, which was about sea torpedoes, one can easily imagine how some readers might have perceived this fish to be just a flat torpedo ray, albeit one discovered in a new and unexpected freshwater location. Given the thousands of miles from the mouth of the Nile 
mouth up to Lake Tana, it could not, however, have been a sea torpedo that managed to migrate upstream.

The ability of this fish to chase demons away also merits comment. It reminds us of what Dos Santos' (1609) had written about "enchantments" being made from the fish. Such lines show us that the missionaries in Africa, both Jesuit and Dominican, were very interested in native superstitions, a subject closely tied to more formal religious rites and beliefs, and one frequently encountered in the writings. What is particularly notable, especially given the brevity of both Fernandes' and Dos Santos' descriptions, is how these deeply religious men distanced themselves away from these beliefs, calling them native superstitions and not endorsing them.

As to the capability of the fish to inducing motion in dead fish, another claim that Fernandes would not endorse, it is worth noting that this could actually happen when a recently deceased fish (or an unmoving but not-quite-dead fish) receives an electric shock. Neither trained in natural history or natural philosophy, nor willing to bring up occult forces, Fernandes could only write that he had no direct experience of this, and "Let those who investigate natural things try to ascertain the cause of this phenomenon, and to search for the force of the motion transmitted by the torpedo to the dead fish."

Yet perhaps most intriguing of all are the statements that, this fish "does not cause problems while it remains still," but that, "if the fish moves a little, it tortures the body." In other words, movements and mechanics are here tied to the "intense affliction accompanied by stupor that this fish can cause." This is significant because mechanical explanations for the numbness caused by electric fish would begin to flourish in the scientific literature only later in the seventeenth century, starting with the texts of Francesco Redi in 1671 and Stefano Lorenzini in 1678 on torpedo rays caught off the coast of Italy (Piccolino, 2003; Finger and Piccolino, 2011). (Although stimulated by comparable observations, what would become the widespread belief that electric fish movements must precede their effects would eventually be found false.)

In contrast to Dos Santos' book, Godinho's text circulated widely. It was the first widely disseminated source to introduce Europeans to an African river fish sharing functional characteristics with the sea torpedoes. It would not, however, be the only such Jesuit book.

\section{Telles' Book and Almeida on the Catfish}

In 1660, another Portuguese Jesuit, Balthasar Telles (or Tellez), published his Historia Geral da Ethiopia a Alta. By this time, there had been a major upheaval in Ethiopia. Afonso Mendes, the new Patriarch appointed by Rome, had arrived in 1626. Lacking Paez' skills and not one for moderation, he tried to abolish all practices that did not conform to Roman Catholicism and made stern demands about religious practices that led to internal wars among the Ethiopians. By 1634, Ethiopian emperor Fasilides had had enough, and this led to the persecution and expulsion of the remaining Catholics, again breaking bonds between his country and Europe.

Although the cultural landscape had changed dramatically, and 45 years had passed since Godinho's text was published, Telles and Godinho have much in common. Most importantly, both writers were involved in the Jesuits' attempt to discredit Urreta's claims about Ethiopia. Additionally, both strove to compile accurate information and neither had stepped foot in Africa, basing their books largely on information they received secondhand from Jesuit missionaries in "the Indias." 
Telles' river fish is described in relation to the animals living in the Tacazee River, which originates about 40 miles south of Addis Ababa and flows into Lake Zeway. After reporting on the presence of crocodiles and "marine horses" (hippopotamuses) in this river, Telles writes:

There are also many fish in this river. Father Manoel d'Almeyda testifies that he was shown here, in a trough, the fish that because of its effect is called Torpedo in Latin; and that seizing it in his hand, he soon received in that hand and his forearm a remarkable shock of such intensity that he quickly released it, having no desire to continue any more with this troublesome experience. (Telles, 1660, p. 21)

Telles' text is a fairly faithful translation of the original passage from Manoel de Almeida's manuscript, which dates from about 1645. After Father Paez had died, Almeida traveled to Ethiopia to help Father Fernandes in Ethiopia. In 1954, an English edition of Almeida's work came forth, and in it this important passage reads as follows:

There are many fish in this river. The first time I crossed it the men who accompanied us gave me one of the kind the Latins call 'torpedo'. Many people, and I too, tested its power in a trough of water. I squeezed it in my hand under the water. I felt my hand so weak and powerless that I let it go very hurriedly. (Beckingham and Huntingford, 1954, p. 31.)

\section{Paez's Unpublished Manuscript}

The texts spawned by Urreta's claims did not, however, just come from desks in Europe. At the request of the Jesuit leadership in Europe and India, Father Paez himself had been encouraged to provide a true picture of Ethiopia, one defending Jesuit claims against what the Dominican had written. Unlike Urreta, Paez accurately investigated the geographical and historical features of Ethiopia, read Ethiopian sacred texts, and asked the natives about many things. One of his sources was the emperor himself, and he even accompanied him to the source of the Blue Nile, where the electric catfish can be found.

When Paez died in 1622, his Historia da Ethiopia, describing what Ethiopia is really like, was still unpublished. It remained so until the twentieth century, when Camillo Beccari (1903-17, vols. II and III) included it in the collected works of the Jesuit missionaries in Ethiopia (also see Paez, 2006). Copies of it did, however, circulate during the seventeenth century and later, so it was hardly unknown, especially in Jesuit circles. Telles, for one, was familiar with it, as was the famous Jesuit, Athanasius Kircher, who was interested in the sources of the Nile and cited it in his Oedipus Aegyptiacus of 1652 (it would also be cited by Nile explorer in James Bruce in 1790).

In its modern edition, what Paez' writes about the fish can be found in his chapter dealing with the course of the Nile. In addition to providing a good description of the sources of the Blue Nile (likely the first by a Westerner), Paez correctly explained the periodic flooding of the river, correcting yet another erroneous theory that Urreta had supported.

With regard to the river torpedo, his description is more extensive than those previously mentioned. It is here that we again encounter João Gabriel, the Captain of the Portuguese soldiers, who Paez regarded as an expert witness: 
There is a great quantity of many kinds of fish here, and fat, because the fish find good food here. And among them there is one we call torpedo in Latin, and that the natives call Adenguêz, which means "fright." This is because, as they say, if one seizes it with his hand and the fish moves, it causes "fright," because it seems as if all of his bones would come apart. This happened to some Portuguese who told me about it, and notably to João Gabriel, who, while fishing with some fellows, caught a fish of more than a span of length, without scales, which was rather similar to a smooth hound fish [i.e., a dogfish; çacam in the Portuguese original], and motionless when he brought it in. He took the fish it in his hand to release the hook, but as soon as the fish moved he quickly let go, because his bones up to his teeth started shaking and seemed to be moving away from his body. Were he not seated he probably would have fallen down. He came back to himself soon after, and realized which kind of fish it was. And in order to play a joke on one of his attendants, he asked him to remove the fish from the hook. As soon the attendant took it in his hand, the fish moved and he immediately fell over, without knowing what had happened to him. When he got up, he said: what could I possibly have done upon you, sir, for you to frighten me in this way? The captain and many of the others of the party laughed out loud, seeing how much the attendant was astonished, not knowing what had happened to him. They waited for the fish to die before taking it off the hook; the captain told me that he regarded it as certain that when the fish does not move it does not produce this effect, because he felt nothing until the fish moved. He added that another Portuguese fisherman caught one of these fish a cubit in length. (Paez, in Beccari, 1903, vol. I, pp. 285-286; vol. II, p. 260)

Paez' physical description of the fish makes it clear that he was not describing a ray. The critical passage here is "a fish of more a span of length, without scales, rather similar to a smooth houndfish." Nevertheless, Paez does not mention facial barbels, a distinguishing feature of catfish. With regard to this omission, he is like Dos Santos (1609), Godinho (1615), and Telles (1660). He is also comparable to Fernandes (in Godinho) when he contends that the fish produces its torporific effects only when it moves and not after death. Very likely, this was something the Portuguese discussed with each other, so as not to repeat a costly mistake.

\section{$\underline{\text { Jobson's English Book }}$}

There is another mention of Malapterurus from the first part of the seventeenth century, and it comes not from Portuguese missionaries but from an Englishman, Richard Jobson, who described himself as a "poore seaman" and also as a "Captaine." He was a Protestant and he believed that King Solomon's rich land of Ophir (as cited in the Old Testament) was in or near Gambia (Gamble and Hair, 1999). Leading a small group of men, he explored the Gambian coast and Gambian River in 1620 and 1621, but unlike other Caucasians on the river, he despised the lucrative slave trade, even though he was monetarily driven.

The Gambian River begins in modern-day Guinea and runs through Gambia to the Atlantic Ocean. Jobson's book on what he encountered came out in 1623 and was titled The Golden Trade: Or, A Discovery of River Gambra. This was the first book to describe the torporific African fish to readers of the English language.

Buckor Sano, an African trader, had told Jobson there was an incredibly rich city called Timbuktu (now in Mali), where even the houses are covered in gold. He explained that Jobson could reach it if he travelled up the river for about two months from his coastal 
location. Jobson, of course, wished to strike it rich in Africa and had the fortitude to set forth on the dangerous journey. He never obtained these great riches, but he did write about his adventures, which included a Gambian River fish that caused quite a sensation.

Amongst the rest, one time having made a draught, we had not plenty as usually, onely some fish, in the cod [bag] of the net, which being taken up, were shackt into a basket standing in the boate, with which we rowed aboord, \& the basket being handed in as the custome is, the fish were powred upon the Decke, whereof many rude Saylers will be their owne carvers amongts which fish, there was one, much like our English breame, but of a great thickness, which one of the Saylers thinking for his turne, thought to take away, putting therefore his hand unto him, so soone as he toucht, the fellow presently cried out, he had lost use both of his hands, and armes: another standing by sayd, what with touching this fish? and in speaking, put thereto his foote, he being bare-legged, who presently cried out in the like manner, the sense of his leg was gone: this gave others, of better rancke, occasion to come forth, and looke upon them, who perceiving the sense to come againe, called up for the Cooke, who was in the roome below, knowing nothing what had hapned, \& being come wild him to take that fish, and dresse, which he being a plaine stayd fellow, orderly stooping to take up, as his hands were on him, suncke presently upon his hindere parts, and in the like manner, made grievous mone: he felt not his hands, which bred a wonderfull admiration amonst us: from the shore at the same time was comming a Canoe aboord us, in which a Blacke man called Sandie, who in regard he had some small knowledge of the Portingall tongue, had great recourse amongts us, we brought him to the fish, and shewed it unto him, upon sight sight whereof, he fell into laughter, and told us, was a fish they much feared in the water, for what he touched hee num'd, his nature being to stroke himselfe upon another fish, who presently he likewise num'd, and then pray'd upon him, but bid us cut of his head: and being dead, his vertue was gone, and he very good to eate. (pp. 29-30)

Jobson deserves credit for telling his readers that the fish is "much like our English breame, but of a great thickness." His physical description, although brief, is clearly informative enough to guide reader away from images of flat torpedo rays to what has to be a physically different fish with similar, if not stronger, powers. His book underwent multiple editions, and abridgments and synopses of it appeared in travel books along with the aforementioned missionary descriptions, as we shall now see.

\section{$\underline{\text { Samuel Purchas }}$}

Samuel Purchas was an Englishman who started editing books on sea voyages in 1613. Living by a flourishing seaport, Purchas had long been stimulated by what he was hearing from returning sailors, although he never travelled far from the town of his birth. He published what would become his most cited work in 1625, calling it Hakluytus Posthumus, or Purchas his Pilgrimes. This monumental, four-volume publication reflected the great interest Europeans had in learning more about exotic lands during the Early Modern Era. It was based on the unpublished papers of Richard Hakluyt, an English writer and collector of travel manuscripts, who he had assisted until his death in 1616.

More than half of Purchas' approximately 700 pages dedicated to Africa deal with Ethiopia. He includes English translations of Jesuit letters and long summaries of various books on Ethiopia. The electric catfish, still indicated as "Torpedo," appears in a section 
called "Description of the Countries, and Severall Regions, Religions, and Abassine Opinions." Here he mentions "Fernandez" and his letter of 1610, which he presents in the English of his day, closely following what Godinho had provided (Purchas, 1625/1905, Vol. VI, part II pp. 1182-1183). He also gives an account of Dos Santos' description of the fish found in the Sofala River in Mozambique, and includes what Richard Jobson wrote in his recent book.

Additionally, the part of Fernandes' letter dealing with the river torpedo is reported in the fourth edition of Purchas his Pilgrimage, or Relations of the World and the Religions, although in a slightly different form. This book dates from 1626 and also covers Urreta's fictional narration, which Purchase states he first thought about omitting and then criticizes for being completely unreliable.

Thus, Purchas, a travel writer, played a significant role in diffusing the discovery of this unusual African freshwater fish to a great number of English language readers. Many of his readers were Protestants, not the Catholics more directly involved in Dominican and Jesuit power struggles and exploits. But as he well knew, Protestants had an interest in what the Catholics were attempting to do abroad and within Europe, while also having a desire to read more secular natural histories and travels. Hence, readers did not have to deal solely with myths and fairytales, like those of Urreta, to meet with fantastic creatures early in the seventeenth century; there was a very real African river torpedo with powers that could stir the imagination, and it was described in several places in Purchas' texts.

\section{Hiob Ludolf, The Father of Ethiopian Studies}

Word about the strange African river fish continued to spread in Europe during the second half of the seventeenth century, helped along by German scholar Hiob (Job) Ludolf. Having a strong penchant for foreign languages, Ludolf learned Ethiopian and Arabic, and even though he too never visited Ethiopia, he has been called the "Father of Ethiopian Studies."

Ludolf, a Lutheran, was especially interested in Ethiopian Christianity and Jesuit attempts to convert the Ethiopians to Catholicism. Concerns about the Ethiopian religion were still receiving considerable attention in Europe, including in Protestant countries, during the closing decades of the century. To those, like Ludolf, who deviated from Catholic orthodoxy, the "difficulties" the Roman Catholics were having with the Ethiopian Church reflected yet another regrettable instance of the unyielding attitude of Rome toward other churches during the Counter-Reformation.

His two volumes on Ethiopia were initially published in Latin, but were translated into various languages and frequently republished. His Historia Athiopica sive Brevis \& succincta descriptio regni Habessinorum, quod vulgò malè Presbyteri Johannis vocatur ("Ethiopian History or a Short and succinct Description of the Kingdom of Abyssinians which is incorrectly said to be Prester John's") came forth in 1681. Ad suam historiam aethiopicam antehac editam commentarius..., or his "Commentary," appeared 10 years later and was a companion piece to the first volume. With extensive resources to draw from, these volumes were based on almost everything that had been written and published about Ethiopia.

The African river torpedo appears in both volumes. Ludolf's 1681 description is based mainly on Godinho text and Almeida's account of the fish, as presented in Telles. But he also mentions Dutch writer Olfert Dapper, who called it a "Drillvisch" and "Zitterfisch." Dapper 
had authored a collection of travel books, first published in Dutch in 1670 and later in other languages, and his account of Ethiopia was largely drawn from Telles.

Ludolf writes that the "Torpedo is very remarkable, frequent in Africa," and "it is of that Prodigious Nature, that if it be touched with the hand, it strikes a most intolerable Trembling into the Members." He continues by adding to the myths already surrounding this fish, namely that the natives use its powers to treat agues (probably forms of malaria), and that it might also be useful for treating gout. In a 1682 English translation of his book, his statements read as follows:

The Habessines cure Quartan and Tertian Agues with it. The manner thus, the Patient is first bound hard to a Table, after which the Fish being applied to his joynts, causeth a most cruel pain over all his Members, which being done, the fit never returns again. A severe Medicine, which perhaps would not be unprofitable to those that are troubled with the Gout, in regard some say that Disease is to be Cured by Torment. Those Ethiopians would certainly believe it, who affirm, that the Venue of this Fish will dispossess a man of the Devil himself. And yet if you touch this Fish with a Spear or a Wand, the sinews of it, though very strong, presently grow numb and the Feet of it, though otherwise a swift runner, lye as if they were bound, as Plinie reports. Which Modern Writers testifie to be no untruth. (Ludolf, 1682, Bk. I, p. 62)

By referring to Plinie (Pliny the Elder) and bringing in the ancient legend of how a torpedo ray could stop a swift runner in his tracks, Ludolf seems to be combining what he had read about two very different fishes (for more on Pliny and torpedoes, see Finger and Piccolino, 2011). Further, sea torpedoes, and not the electric catfish, had been used to treat gout since ancient Roman times (Scribonius, 1983; Finger and Piccolino, 2011).

In his 1691 Commentarius, where what Godinho and Telles had about the freshwater African torpedo appears, and after also mentioning Dapper, Ludolf writes:

It is also found in Africa. About it Caspar Barlaeus in his very beautiful work de rerum in Brasilia gestis p. 134 writes It is assured that there is here the Torpedo, called Puraquam by the Barbars [i.e., the natives], because it induces torpor in the members, and even if you touch it with a stick: after being killed it loses its venom and can be eaten. This experience confirms that were true the things the ancients wrote about this fish and among them Pliny Lib. 32. c.1. \& 10. (Ludolf 1691, pp. 160-161) (Fig. 7)

By referring to Dutch scholar Barlaeus (Casper van Baerle) in addition to Pliny, Ludolf now seems to have melded stories about three very different torporific fishes together. Barlaeus wrote about Brazil and was likely describing the electric eel. These confusions with the torpedo ray and the South American eel would, unfortunately, continue to characterize the literature on the catfish, and this would not be due solely to the fact that Ludolf's works had an immense circulation within Europe. It also reflected the fact that what was now being written about the African catfish was only rarely based on personal experiences. There were exceptions, however, such as a short notation on the presence of "the Reade [i.e., the ra'ad], or the Cramp-Fish" in the Nile. It appears in The Present State of Egypt, a book published in French in 1677 and in English in 1678. The book's author, Johann Michael Wansleben (or Vansleb), was a German Dominican who had been in Egypt twice, so most likely he at least knew the fish firsthand. 
Ethiopian Christianity and Religious Intolerance

The great interest shown by Protestants during the seventeenth century in Ethiopia and its relations with the Roman Catholic Church had its counterpart in the interest shown by Christian liberals during the previous century. In 1541, stimulated by the arrival of Ethiopian monk Şāgä Z ä’ Äb (or Zagazabo; literally "Grace of the Father") in Lisbon, Góis, a Catholic who had been a student of Erasmus of Rotterdam, took the occasion to expound his views about religious tolerance. In his treatise, Góis (1541) included various relevant texts dealing with European-Ethiopian relations, most notably a defense of Ethiopian religion written by Zagazabo himself (Pennec, 2003; Marcocci, 2005).

During Ludolf's time, Protestant interest in Ethiopia led to more publications. One of particular relevance was Geddes' Church History of Ethiopia, published in 1696. The lengthy subtitle informs the reader that it contains "An Epitome of the Dominican [i.e., Urreta's] History of that Church." As might be expected, Urreta's book was treated extremely harshly.

Two publications of somewhat apocryphal authorship stand among the most memorable editorial events in this highly charged atmosphere. As the long title of the first one made clear, it concerned "the rebellions and bloudshed occasioned by the anti-Christian practices of the Jesuits and other popish emissaries in the empire of Ethiopia" (Wansleben, 1679). It was based "on a manuscript written in Latin, by Jo. Michael Wansleben, a learned papist." Its author was the same Wansleben who mentioned "the Reade or the Cramp-Fish" in his travels to Egypt. Having been Ludolf's student and an expert of oriental languages, Wansleben had co-edited the Confession of Claudius [Gelawdewos] (with original text and Ludolf's Latin translation), published in London in 1661 (Ludolf and Wansleben, 1661). Although born a Lutheran, Wansleben converted to Catholicism and in 1666 had become a Dominican.

The manuscript on which the anti-Jesuit pamphlet bearing his name was based had been prepared during his first voyage to Egypt, in 1663 (i.e., before he converted to Catholicism). It was an account of the history of the Jesuit missions, as requested by the Duke of Saxony (Bausi, 1989). The anonymous author of the Preface presents the reasons why the Protestants were so interested in Ethiopia and what the Catholics wanted to do there. After discussing how the Catholic Church promotes "subversion by the force of the Arms" when it does not succeed in proselytism "by the force of the Arguments," he writes:

This is a Truth which more than one Age and Nation had sadly experienced, but none ever had more reason to abhor and deprecate than Ours. Yet the well-ordered Governments of our British Church and State is not the sole Object of the Roman envy, not hath England been the only Scene of the Popish Cruelty. Not to mention the known and memorable Instances of Paris, Piedmont, Ireland \&c. Ethiopia, a Country little known and less frequented by the English, has felt the smart of Rome's malice, and bears fresh Scars of the Jesuits Treachery. [Italics in original]

The second important editorial event occurred in 1670 with the publication of book in London titled, "The Late Travels of S. Giacomo Baratti, an Italian Gentleman, into the Remote Countries of the Abissins [sic], or of Ethiopia Interior." According to the English editor (signed G. D.), this was a translation of a book published twice in Italy with "universal applause." Yet, as pointed out by Tedeschi (1992), both Baratti and his travels were born of fantasy, there only being an English edition. The contents of the book, and particularly the 
contrasts made between the Ethiopian and Roman Catholic Church, and the inclusion of documents from the previous century (Zagazabo's defense of Ethiopian religion taken from Góis' Latin version), clearly show that a Protestant wrote it as an anti-Catholic polemic. In some ways, Baratti's book is the Protestant counterpart of Urreta's books, although he lacks the verbosity and rhetoric of the Spanish monk.

The great interest in Ethiopia's religion, which had drawn so much attention in the sixteenth century, continued in the next century. As a result, people who read monographs or collections about Ethiopia became progressively more aware that a fish functionally similar to the sea torpedo, but with a different appearance and capable producing a much stronger effect, was present in some African rivers and lakes.

\section{The Catfish Becomes Electrical}

Seventeenth-century reports on the African catfish were decidedly brief, un-systematic, and not at all "philosophical." Nowhere does one find a discussion or any explanation of its remarkable powers. This void is understandable from several perspectives. One is that the descriptions came largely from missionaries and traders, who, although inclined to give accurate descriptions of what came to their attention, were not well-trained natural philosophers focusing on causes of the phenomena they were observing. Rather, their explorations were more tied to religion, trade, the search for treasures, and political maneuvering than to science.

A second important factor is that natural philosophers had been stymied by the actions of the saltwater torpedo since antiquity. Galen, among others, entertained notions that they release some sort of cold venom with torporific effects, although he also considered other hypothesis (Finger and Piccolino, 2011). So did others who followed him, still perplexed by how the release of a poison could be transmitted to a person's hand through the water, a wet net, or a metal rod. As a result, many Medieval and Renaissance writers either alluded to occult or magical powers or simply did not attempt to discuss how the torpedo could torpify, concerning themselves instead with other matters, such as how live or even dead fishes might be used in medicine (Finger and Piccolino, 2011).

The mixing of true descriptions based on personal experiences with more or less fantastic accounts of extraordinary animals must be regarded as a third factor that impaired a good understanding of these fishes. This blending of the real with the unreal has roots in antiquity (Pliny being an excellent example) and it continued during the Middle Ages and into the Renaissance, with people thirsting for legendary tales, magic, and books covering Nature's wonders (e.g., the basilisk, an imaginary serpent-like beast that could kill with just its gaze). Although this attitude was absent in the first-hand descriptions of the African catfish, it continued to occur with some frequently in zoological compilations and travel books. In this context, we can point to Caspar van Baerle, who we mentioned as Barlaeus when discussing Ludolf. After referring to the pouraquê (torpedo) in his account of Brazil, he mentions "fish with human visage," "who exhibit sinuous hairs and a face more elegant of that of a woman, adding "it is said that those fish kill men by compression during intercourse, not purposely, but because of their excessive desire" (Van Baerle, 1660, p. 225).

As briefly noted, it was not until the end of the seventeenth century that a new theory to explain the actions of the torporific fishes began to circulate among natural philosophers who had found previous theories faulty or too mystical. The change in thinking was brought about by Francesco Redi, who was affiliated with the Accademia del Cimento in 
Florence, and his student Stefano Lorenzini. Influenced by the experimental approach fostered by Bacon and Galileo, they conducted experiments on live torpedo rays and dissected them. They then suggested that the torpedo produces its effects by rapid mechanical actions involving special muscles. This theory, inspired by a new mechanical approach to the sciences, based on reported movements of the fish prior to numbing a victim (e.g., as depicted in Fernandes' letter), and tied to the trembling a live torpedo could induce, drew many adherents, including René-Antoine Ferchault de Réaumur (1717), who studied torpedoes in his native France. It had several variations and, although it was not particularly adept at explaining actions at a distance, it dominated the literature until the Zeitgeist began to change in the second half of the eighteenth century.

Electricity had become the topic of the day at this pivotal point in time. With improved machines and great faith in experiments, Benjamin Franklin captured electricity from the heavens and showed it was qualitatively the same as the electricity he could generate with his static machines and store in newly invented Leyden jars (Ritterbush, 1964; Heilbron, 1979; Finger, 2006; Finger and Piccolino, 2011). It was in this rapidly changing intellectual environment that the discharges of electric fishes began to be directly compared to those from electrically charged Leyden jars. The favorable comparisons that began with South American eels was enhanced by the realization that the discharges of these fish could be transmitted through known conductors of electricity (e.g., metal rods, moist bodies) but not through nonconductors (e.g., glass). Although considerably less was written about the African catfish than the eel or torpedoes at this time, it nevertheless played an important role in this emerging picture, which ultimately led to a better appreciation of animal electricity.

\section{Adanson's Catfish}

Michel Adanson, who lived in the African country of Senegal from 1749-53, was the traveler and naturalist who, more than anyone else, brought the rather overlooked catfish to the attention of natural philosophers during the Enlightenment, and he did so with electricity very much on his mind. His description of the African river torpedo dates from September 1751, although his Histoire Naturelle du Sénégal was not published until 1757 (with an English edition in 1759). Adanson's section of interest is labeled Poisson Trembleur ("Trembling Fish" in English editions). He informs his readers that his tremble fish is "round without scales, and smooth as an eel, but much thicker in proportion to its length" (Fig. 8). This river fish cannot be a flat ray. More importantly, he states, at least in the French edition of 1757, that it also has facial barbels, a distinguishing feature of catfishes.

He further writes, "the negroes call it ouaniear, and the French trembleur, or quaker, from the effect it produces, which is not a numbness like that arising from the cramp-fish, but a very painful trembling in the limbs of those who touch it" $(1759$, p. 244). His next sentence is decidedly more memorable, because he had personally experimented with a Leyden jar. Here he writes: "This effect did not appear to differ sensibly from the electrical motion of the Leyden experiment, which I had felt several times, and it is communicated in the same manner by simple contact, with a stock or iron rod of iron five or six feet long; so as to make you instantly drop whatever you hold in your hand" (1759, pp. 244-245). Adanson states that he has "tried this experiment several times," cognizant of the power of experiments and knowing the demand for replicable findings in the new science.

In 1772, when John Walsh set forth from London to conduct electrical experiments on torpedoes found off the western coast of France, he stopped in Paris where tried to learn more 
from Adanson, although it is not certain that he spoke with him (Piccolino, 2003). Walsh (1773) would later write back to Franklin, who helped him plan his electrical experiments, that torpedoes show many properties that had convinced him that they are, in fact, electrical, although he could not include moving pith balls or seeing a spark among his notable achievements. In 1776, using more powerful electric eels just imported to London, Walsh was able to obtain replicable sparks from the eel, providing crucial evidence in favor of fish electricity.

Six years after Walsh's landmark achievement, French zoologist Pierre Marie Auguste Broussonet provided the first clear morphological description of the electric catfish (Broussonet, 1782; Fig. 9). This laid down the basis for a definite distinction of this animal from the other electric fishes. It would help to reduce the errors and confusions that were continuing at this time, as for instance those of John Pringle (1775), who had been the President of the Royal Society of London, and thereafter Marcus Elieser Bloch (1786-87), the eminent German zoologist, both of whom confused the catfish with the eel.

\section{Closing Comments}

The eighteenth century was a century of great revolutions, when monumental political and social changes took place in North America, Europe, and elsewhere. It was also a century of important scientific revolutions, although they took more time to be fully realized. It was during the second half of this century that loose and unsubstantiated ideas about the physiology of the nervous system finally began to crumble under the weight of good experiments. The physiological paradigm shift that ensued stemmed from the inadequacy of earlier theories to account for the facts and the awareness that scientists could provide evidence that living organisms, at first just a few specialized fishes, could actually be electrical.

Although torpedo rays and electric eels were the more important experimental subjects at the start of this revolution, the catfish encountered by Portuguese missionaries to Ethiopia and nearby lands early in the 1600s helped to change perceptions. Moreover, the place of this fish in the history of the physiology and medicine did not end with Adanson, with whom we ended this review. During the nineteenth century, a number of electric catfish were imported to Europe, where they were used in important nerve and muscle studies, and in research aimed at one of the most intriguing features of all strongly electric fishes, their ability to stun smaller fishes and to even numb a human hand, while not causing harm to themselves or others of the species. These studies were conducted by Emil du Bois-Reymond and his associates in Germany, Francis Gotch in England, and others who seemed as fascinated with these fish as Dos Santos, Fernandes, Jobson, and others had been well over two centuries earlier, when they experienced their remarkable powers (see Finger and Piccolino, 2011).

The scientific journey of the electric catfish is colorful, and it had long been wrapped in myths, confusions, and misperceptions. As we have seen, it can be tied to King Solomon and the Queen of Sheba, the Magi, and Prester John. It is a history centered mainly on the Portuguese in Africa, and it has deep and important links to strong but differing religious beliefs. Yet it is also a story that involves others: an English sea captain, a collectors of travel stories, a scholar interested in foreign languages, and a Frenchman who knew about the newly discovered Leyden jar and conducted some telling experiments on the catfish in the best spirit of the Enlightenment. 
In a very real way, this historical review shows the complexity and at times the unpredictable nature of scientific achievements. It also reveals how what transpires in the sciences can have roots penetrating deeply into unexpected areas or fields, such as religion. Clearly, all histories are intertwined, or as put by French historian Marc Bloch: "the only true history, which can advance only through mutual aid, is universal history" (Bloch, 1949; trans. 1954 p. 47). 
Acknowledgements.

We thank Alessandro Bausi, Adriano Prosperi, Nicholas Wade and Gioia Zaganelli for critically reading previous versions of this article. 


\section{$\underline{\text { References }}$}

Adanson M (1757): Histoire Naturelle du Sénégal. Paris, Bauche.

Adanson M (1759): A Voyage to Senegal, The Isle of Goree, and the River Gambia. London, Printed for J. Nourse and W. Jonhston [sic.].

Alfonso Mola M, Martinez Shaw C (2004): Pedro Páez y la misión jesuítica en Etiopía en el contexto de la unión de las Coronas de España y Portugal. ETF, Ser IV, Hist Mod 17: 59-75.

Allamand JNS (1754): Bericht der Geneezinge van een Meisken, met een zeker soort van beroerdheid bezet, dewelke door hulp van electriciteit hersteld is. Verh Holl Maatsch Weetensch Haarlem 2: 372-379.

Alonso Romo EJ (2006): Andrés de Oviedo, Patriarca de Etiopía. Rev Estud Ibér 3: 215-231

Alvares F (1540): Ho Preste Ioam das Indias: verdadera informaçam das terras do Preste Ioam. Lisboa, Luis Rodriguez.

Baratti G [pseud.] (1670): The Late Travels of S. into the Remote Countries of the Abissins, or of Ethiopia, Interior.... London, Printed for Benjamin Billingsley.

Basset R (1893-1900): Les Apocryphes éthiopiens, 10 voll. Paris, Librairie de l'art indépendent.

Bausi A (1989): I manoscritti etiopici di J. M. Wansleben nella Biblioteca Nazionale Centrale di Firenze. Rass Studi Etiop 33: 5-33.

Beccari C. (1903-17). Rerum aethiopicarum scriptores occidentales inediti a saeculo XVI ad XIX. 15 voll. Romae, C. de Luigi.

Beckingham CF, Huntingford, GWB (1954): Some Records of Ethiopia, 1593-1646... London, The Hakluyt Society.

Bloch M (1949): Apologie pour l'Histoire; ou, Métier d'Historien. Paris, A. Colin, 1949. (English translation by P Putnam, The Historian's Craft, Manchester, Manchester University Press, 1954.)

Bloch ME (1786-87): Naturgeschichte der ausländischen Fische. Berlin, Aus Kosten der Verfassers, und in Commission in der Buchhandlung der Realschule.

Broussonet, PMA (1782): Sur le trembleur, espèce peu connue de poisson électrique. Hist Acad R Sci: 692-698.

Bruce J (1790): Travels to Discover the Source of the Nile, in the Years 1768, 1769, 1770, 1771, 1772 \& 1773 (5 vols.). Edinburgh, Robinson. 
Caraman P (1985): The Lost Empire: The Story of the Jesuits in Ethiopia, 1555-1634. London, Sidgwick and Jackson.

Castanhoso M (1564): Historia das cousas que o muy esforcado capitão Dom Christouão da Gama fez nos Reynos do Preste Ioão com quatroce[n]tos Portugueses que consigo leuou. Lisboa, Barreira.

Cerulli E (1943-47): Etiopi in Palestina; storia della comunità etiopica di Gerusalemme (2 vols.). Roma, Libreria dello Stato.

Cerulli E. (1968): La Letteratura Etiopica: l'Oriente Cristiano nell'Unità delle sue Tradizioni, 3rd Ed. Firenze, Sansoni.

Conti Rossini C (1894): Storia di Lebna Dengel,re d'Etiopia, sino alle prime lotte contro Ahmad Ben Ibrahim. Roma, Reale Accademia del Lincei.

Conti Rossini C (1928): Storia d'Etiopia: Parte Prima, dalle Origini all'Avvento della Dinastia Salmonide. Bergamo, Istituto Italiano D'Arti Grafiche.

Conti Rossini C (1940a): Portogallo ed Etiopia. In Relazioni Storiche fra Italia e Portogallo: Memorie e Documenti. Roma, Reale Accademia d'Italia.

Conti Rossini C (1940b): Sulle missioni domenicane in Etiopia nel secolo XIV. Atti Reale Acc i Lincei; Rendiconti Classe Sci Mor Stor. Ser VII, 1: 71-98.

Conti Rossini C (1941): Le sorgenti del Nilo Azzurro e Giovanni Gabriel. Boll Soc Geograf Ital 6: 38-47.

Conzelman WE (1895): Chronique de Galâwdêwos (Claudius), Roi d'Ethiopie. Texte Éthiopien. Paris, E. Bouillon.

Doresse J. (1957): L' Empire du Prêtre-Jean (2 vols.). Paris, Plon.

Dos Santos, J. (1609): Ethiopia Oriental e Varia Historia de Cousas Notaveis do Oriente. Evora, Manoel de Lyra.

Finger S (2006): Doctor Franklin's Medicine. Philadelphia, University of Pennsylvania Press.

Finger S, Piccolino M (2011): The Shocking History of Electric Fishes: How they Changed Science and Medicine. New York, Oxford University Press.

Figuier L (1869): Les Poissons, les Reptiles et les Oiseaux (2nd ed.). Paris, Hachette et Cie.

Geddes M (1696): The Church-History of Ethiopia Wherein among other Things, Two Great Splendid Roman Missions into that Empire... London, Chiswell. 
Godinho N (1612): Vita Gonzali Sylveriae, Soc. Jes. Sacerdotis in urbe Monomatapa martyrium passi. Lugduni, Sumptibus Horatij Cardon.

Godinho N (1615): De Abassinorum rebus: déque Athiopice Patriarchis Ioanne Nonio Barreto, \& Andrea Oviedo, Libri Tres. Lugduni, Sumptibus Horatij Cardon.

Góis D de (1541): Fides, religio, moresque Aethiopum sub imperio Preciosi Ioannis (quem vulgoÌ Presbyterum Ioannem vocant)... Parisiis, Apud Christianum Wechelum.

Guerreiro F (1611): Relaçam annal das cousas que fizeram os padres da Companhia de Iesus, nas partes da India Oriental ...com mais hua addiçam aì relaçam de Ethiopia. Lisboa, Pedro Crasbeeck.

Heilbron JL (1979): Electricity in the 17th and 18th Centuries. A study of Early Modern Physics. Berkeley, University of California Press.

Hofmeister A (1912): [Otto Bishop of Freising] (1912). Ottonis episcopi fringensis chronica; sive, historia de duabus civitatibus. Hannoverae, Lipsiae, Impensis Bibliopolii Hahniani.

Ingram D (1750): New experiments concerning the torpedo. Student Oxford Mo Misc 2: 49-52.

Jobson R (1623): The Golden Trade, or, A Discovery of the River Gambra.... London, Okes and Bourne.

Kircher A (1652): Oedipus aegyptiacus, hoc est universalis hieroglyphicae veterum doctrinae... instauratio. Roma, ex typographia Vitalis Mascardi.

Koehler PJ, Finger S, Piccolino M (2009): The 'eels' of South America:

mid-18th-century Dutch contributions to the theory of animal electricity. J Hist Biol 42: 235251.

Lefevre R (1944-47): Riflessi Etiopici nella Cultura Europea del Medioevo e del Rinascimento. Atti Lateranensi, I parte (1944) 8: 9-89; II parte (1945) 9: 332-444; III parte (1947) $11: 255-342$.

Lorenzini S (1678): Osservazioni intorno alle torpedini. Firenze, Onofri.

Ludolf H, Wansleben JM (1661): Confessio Fidei Claudii regis Aethiopicum notis et versione Latina Jobi Ludolfi .... London, Thomam Roycroft.

Ludolf H (1681): Historia Aethiopica, sive brevis et succincta descriptio regni Habessinorum... Francofurti ad Moenum, Apud D Zunner, Typis B C Wustii.

Ludolf H (1682): A New History of Ethiopia: Being a Full and Accurate Description of the Kingdom of Abessinia, Vulgarly, though Erroneously called the Empire of Prester John. 
London, Printed for Samuel Smith.

Ludolf H (1691): Hiobi Ludolphi ad suam Historiam Aethiopicam antehac editam commentarius... Francofurti ad Moenum, Sumptibus J. D. Zunneri.

Marcocci G (2005): Gli umanisti italiani e l'impero portoghese: una interpretazione della "Fides, Religio, Moresque Aethiopum" di Damião de Góis. Rinascimento 45: 307-366.

Moller P (1995): Electric Fishes, History and Behavior. London, Chapman \& Hall.

Nelson JS (2006): Fishes of the World, 4th Ed. Hoboken, John Wiley \& Sons, Inc.

Norris S M (2002): A Revision of the Electric Catfishes, Family Malapteruridae (Teleostei Siluriformes) with Erection of a New Genus and Descriptions of Fourteen New Species and an Annotated Bibliography. Tervuren, Musée Royal de l'Afrique Centrale. (Ser. Zoologische Wetenschappen, No. 289.)

Paez P (2006): Historia de Etiopía: Vivencias de un Jesuita en el Siglo XVII : Descubridor de las Fuentes del Nilo Azul. R Egiguren (ed.). En Port, Eguzkilore

Pennec H (2003): Des Jésuites au royaume du prêtre Jean (Ethiopie) : stratégies, rencontres et tentatives d'implantation, 1495-1633.

Paris, Lisboa, Centre Culturel (Fondação) Calouste.

Piccolino M (2000): The bicentennial of the Voltaic battery (1800-2000). The artificial electric organ. TINS 23: 47-51.

Piccolino M (2003): The Taming of the Ray, Electric fish Research in the Enlightenment, from John Walsh to Alessandro Volta. Firence, Olschki.

Piccolino M, Bresadola M (2002): Drawing a spark from darkness: John Walsh and electric fish." TINS 25: 51-57.

Piccolino M, Bresadola M (2003): Rane, Torpedini e Scintille, Galvani, Volta e l'Elettricità Animale. Torino, Bollati-Boringhieri.

Pringle J (1775): Discourse on the Torpedo Delivered at the Anniversary Meeting of the Royal Society, November 30th, 1774. London, Printed for the Royal Society.

Purchas S (1625): Hakluytus Posthumus, or Purchas his Pilgrimes: Contayning a History of the World in Sea Voyages and Lande Travells by Englishmen and Others. (4 vols.). London, Printed by W. Stansby for H. Fetherstone.

Purchas S (1626): Purchas his Pilgrimage, or Relations of the World and the Religions Observed in All Ages and Places Discovered, from the Creation unto this Present... (4th ed.). London, Fetherstone. 
Réaumur RAF (1717): Des effets que produit le poisson appelé an français torpille, ou trembleur, sur ceux qui le touchent; et de la cause dont ils dépendent. Hist Acad R Sci (pour l'Année 1714): 344-360.

Redi F (1671): Esperienze Intorno a Diverse Cose Naturali e Particolarmente Interno a quelle che ci son Portate dall'Indie.... Firenze, All'insegna della Nave.

Ritterbush, PC (1964): Electricity: the soul of the universe. In Overtures to Biology: The Speculations of Eighteenth-Century Naturalists. New Haven, Yale University Press, pp. 1556.

Scribonius Largus (1983): Scribonii Largi Compositiones. S Sconocchia (Ed.). Leipzig, Teubner.

Slessarev V (1959): Prester John. The Letter and the Legend. Minneapolis, University of Minnesota Press.

Telles B (1660): Historia geral da Ethiopia a alta. Coimbra, Manoel Diaz.

Tedeschi S (1992): Giacomo Baratti e il suo presunto viaggio in Abissinia. Africa 47: 1-27.

Urreta L (1610): Historia eclesiastica, politica, natural, y moral, de los grandes y remotos reynos de la Etiopia, monarchia del emperador, llamado Preste Iuan de las Indias ... Valencia, Mey.

Urreta L (1611): Historia de la Sagrada Orden de Predicadores, en los remotos reynos de la Etiopia.... Valencia, Chrysostomo Garriz.

Van Baerle C (1660): Rerum per octennivm in Brasilia et alibi gestarum... historia (2nd ed). Clivis, Silberling.

Van der Lott F (1762): Kort bericht van den conger-aal, afte drilvisch. Verh Holl Maatsch Weetensch Haarlem 6: 87-94.

Volta A (1800): On the electricity excited by the mere contact of conducting substances of different species. Letter to Sir Joseph Banks, March 20 1800. Phil Trans R Soc 90: 403-431.

Wagner B (2000): Die Epistola Presbiteri Johannis.Tübingen, Niemeyer.

Wallis Budge EAT (1928): A History of Ethiopia, Nubia \& Abyssinia (According to the Hieroglyphic Inscriptions of Egypt and Nubia, and the Ethiopian Chronicles). London, Methuen.

Walsh J (1773): On the electric property of Torpedo: in a letter to Ben. Franklin.... Phil Trans $R$ Soc 63: 461-479. 
Wansleben JM (1677): Nouvelle Relation en Forme de Journal d'un Voyage Fait en Egypte, 1672-73. Paris, Michallet.

Wansleben JM (1678): The Present State of Egypt, or, A New Relation of a Late Voyage into that Kingdom Performed in the Years 1672 and 1673. Englished by M.d., B.D. London, Printed by R.E. for John Starkey.

Wansleben JM (1679): A Brief Account of the Rebellions and Bloudshed Occasioned by the Anti-Christian Practices of the Jesuits and other Popish Emissaries in the Empire of Ethiopia Collected out of a Manuscript History Written in Latin by Jo. Michael Wansleben, a Learned Papist. London, Edwin.

Whiteway RS (1902): The Portuguese Expedition to Abyssinia In 1541-1543, as Narrated by Castanhoso, the Short Account of (João) Bermudez, and Certain Extracts from Correa with Some Contemporary Letters. London, Hakluyt Society.

Zaganelli G (1992): La lettera del Prete Gianni. Parma, Pratiche.

Zarncke F (1879-83): Der Priester Johannes (2 vols). Leipzig, Sachsische Akademie der Wissenschaften. 


\section{Figure Captions}

Fig. 1. The electric catfish in a nineteenth century illustration (From Figuier, 1869).

Fig. 2. An old fictitious representation of Prester John and an ancient map of the eastern regions of Africa in which Ethiopia is indicated as Prester John's Empire, following a established during the Middle Ages,.

Fig. 3. The title page of the first historical account of Ethiopia written by the Portuguese priest and member of the embassy to the country, Francisco Alvares, and published in Lisbon in 1540.

Fig. 4. The 1610 and 1611 volumes by Spanish monk Luis de Urreta, which present a totally fictitious account of Ethiopia based on the Prester John's legend.

Fig. 5. The frontispiece of Dos Santos (1609) book showing his representation of Ethiopia. This is the first book by a Westerner to describe the African "Torpedo."

Fig. 6. The cover page the pages of Nicolao Godigno's De Abassinorum rebus, and the pages showing his Latin translation of the part of the Antonio Fernandes' 1610 letter describing Ethiopia's freshwater "torpedo" (i.e., its electric catfish).

Fig. 7. Hiob Ludolf's portrait from his 1691 Commentarius on the history of Ethiopia, with pages from the same work dealing with the Ethiopian torpedo.

Fig. 8. Michel Adanson (1727-1806) and the page of his 1757 book on Senegal, in which he hypothesizes that the shock of the African catfish is electrical in nature.

Fig. 9. The first scientific representation of the electric catfish (From Broussonet, 1782). 